Jurnal Pena Sains Vol. 5, No. 2, October 2018

p-ISSN: 2407-2311

e-ISSN: 2527-7634

\title{
THE ANALYSIS OF PEDAGOGICAL CONTENT KNOWLEDGE (PCK) SUBSTANCE IN PRE-SERVICE SCIENCE TEACHERS' SKILLS TO ANALYZE ESSENTIAL MATERIAL OF SCIENCE
}

\author{
Aris Rudi Purnomo ${ }^{1}$ and Siti Nurul Hidayati ${ }^{2}$ \\ ${ }^{1,2}$ Department of Science, Faculty of Mathematics and Natural Sciences, Surabaya State University \\ arispurnomo@unesa.ac.id
}

Accepted: Sept 27, 2018

Published: November 20, 2018

\begin{abstract}
Skills to analyze essential material are compulsory for pre-service science teachers, especially by the substance of PCK (elements for the professionalism of science teachers). Therefore, this study aimed at describing the ability of pre-service science teachers in analyzing the essential material of science regarding PCK substance, namely organizing science material. This observational research used a rubric to record quantitative data and research note for qualitative data. The data then analyzed descriptively. As a result, the competence of pre-service science teachers in analyzing the essential material of science is good enough. However, there are only some shortcomings related to the use of propositions in the concept mapping, the connection between concept domain, and extracting learning indicators that can suffice basic of competence.
\end{abstract}

Keywords: Pre-service science teachers, essential material of science, PCK, and basic competence 


\section{Introduction}

The problems that arise in science learning are often focused on the ability of science teachers in teaching learning materials, besides of course they come from students and the interaction between both of them. Nancy (2014) sees, if viewed from teacher competency, the root of the problem comes from the level of teacher professionalism that refers to pedagogical content knowledge (PCK). PCK contains three domains, namely knowledge of teaching material (subject matter knowledge), general pedagogical knowledge, and understanding of the learning context knowledge of context).

When we speak about the ability of science teachers in the context of PCK, then the first thing to attention needs to be paid to the substance at mastery of teaching material and mapping. The main points in a systematic sequence by paying attention to the minimum curriculum requirements that must be mastered by students (Tepner in Jütner, Boone, Park, Neuhaus (2013) and Yohafrinal, Damris and Risnita, 2015). Some studies show that mastery of this aspect is still relatively low in some science teachers. Fauziah exploration results (2011), the majority of science teachers are not yet certified, has a deficiency concerning preparing creative learning which needs to be formulated first in the cognitive domain of the teacher, namely at the planning stage. This stage requires the teacher to understand the essence of the material well and make operational learning objective. Others, Purwana (2010) and Pudjiastuti, Raharjo, and Widodo (2012) found mastery of teaching materials and the transformation has not been wholly owned adequately science teacher who made a tremendous contribution to the success or failure learning in the classroom.
Consistent with the above results, the emergence science teachers at the level of "ordinary" creating speculation about a misunderstanding of the student as science pre-service teacher restricted material content and skills in the preparation of the learning hierarchy. Agustina (2015) identified identification generally the competency of the teacher candidates in the realm of material content is quite good. It is just when asked to draw up a learning plan; prospective teacher students experience difficulties because they have to connect their thinking concepts to the systematic thinking patterns that students must master in stages, as formulated in Bloom's taxonomy. This is in line with the results of observations, the Science Department students who are currently programming the Study of Curriculum course, apparently have not been able to compile indicators whose level of thinking is equivalent to the basic competencies (BC) required. For example, in the basic competency: "Analyzing the occurrence of environmental pollution and its impact on the ecosystem." Apparently, in the BC, that minimum $\mathrm{BC}$ can be achieved by using the level of thinking of the $\mathrm{C} 4$ level analysis. This level requires students to be able to find a form of systematic connection to the fragments of knowledge so that a holistic understanding of a topic is learned (Anderson and Krathwohl, 2014, p. 120). Indicators made by general students use operational verbs such as explaining, giving examples, and describing the level of thinking related to learning to remember (rote learning).

That requires an effort to understand and skills of the student as science pre-service teachers can increase. Cheng, Jang, and Chen (2014) combine collaborative learning and the use of internet wiki software to shape the mindset and skills of teachers to apply PCK and technology at the same time. As 


\section{Purnomo and Hidayati}

a result, prospective teachers, in the end, can plan the educational process 1 teachings useful and able to adopt the components of PCK, so the result is creative learning. Another strategy, Nancy (2014) uses tutor method (one-to-one mentoring) from experienced teachers (experienced teachers) to prospective teachers or teachers at the beginner level (beginning teachers). This strategy is an apprenticeship so that prospective teachers can learn and discuss directly through the exchange of information and ideas. Kartal, Ozturk, and Ekici (2012) have almost the same views. PCK can be taught by microteaching lesson study. The teacher can confidently express the knowledge he composes through the transfer of knowledge of material content to pedagogical knowledge.

Through the study of the literature above, the development of teachers' abilities towards PCK is based more on patterns of knowledge interaction between material content and mapping. For this reason, this article will review the science analysis skills of essential material in this context for prospective science teacher students who use a discussion and presentation approach. This approach is seen to be able to strengthen cognitive abilities (Lazarowitz, Lazarowitz, and Baird, 1994) and affective aspects such as involvement in learning, social elements ( Mondéjar and Pastor, 2017), and selfconfidence each learner or in this case is a prospective science teacher.

\section{Research Method}

This research is observational research. The subject of the study is the student's teacher of science teacher candidates; 16 students program the Curriculum Study program. Study course The curriculum is a course whose focus is analyzing the science curriculum based on aspects of PCK, the breadth of content in $\mathrm{BC}$ and systematics of thought processes to achieve demands on the $\mathrm{BC}$. The data collection is done by assessing the document worksheets from four different teams, using a scoring rubric that contains an aspect of the adequacy of the level of cognitive (manufacture indicator) and the complexity of teaching materials (concept maps). For rubric Indicators, when ratings began from 1 to 4 based on the completeness of the essential elements that must be present in every aspect. Value 1 is equivalent to low ability, value 2 for adequate ability, value 3 for good ability, and value 4 for excellent ability in the rubric on concept maps, assessments made of structure and content. Structure refers to the adequacy of drafting hierarchies of concepts (general and specific concepts) and the relationship between domains of concepts; while content is aimed more at the use of appropriate concepts and the use of conjunctions (propositions). The rating scale starts from 1 to 3 ; value 1 for concept map level 1 (not good), value 2 for concept map level 2 (good), and value 3 for concept map level 3 (perfect) (Cañas, Novak, and Reska, 2015). Each assessment was analyzed by connecting each value obtained by the group with the assessment criteria. That way, the skills of prospective science students to analyze essential material can be well described.

\section{Results and Discussion}

In this article, the discussion of the analysis of essential material the substance of PCK will be limited to two aspects, namely the scope of content in the concept map and translation of $\mathrm{BC}$ into the indicator. But beforehand, in this section, we will first discuss the characteristics of science materials in the 2013 curriculum. 
Characteristics of Science Materials in 2013 Curricula

Based on the 2013 curriculum, the science material divided into three fields, namely the fields of biology, physics, and chemistry. Each has a different proportion, different, $40 \%$ in the biological field, $35 \%$ in physics midwives, and $15 \%$ in chemistry. The three areas are independent, and some are integrated. Physics and biology materials that stand alone are presented in the VII grade curriculum, respectively in $\mathrm{BC} 3.1$ and 3.6 which reads "Applying the concept of measuring various quantities using standard units (standard)" and "Identifying organizational systems of life from the cellular level to the organism and the composition of the main constituents of the cell" .

$\mathrm{BC}$ was showing for integrated material exemplified at BC 3.4 grade VII, namely "Analyzing the concept of temperature, thermal expansion, heat, heat transfer, and their application in everyday life including mechanisms maintain stable body temperature in humans and animals." This BC connects some concepts of physics, temperature, with the concept of thermoregulation in the body of living things as an effort to maintain homeostasis. Most of the others are not connected because this requires more complex constellation and understanding.

In the context of the thinking domain, the highest level for SMP science is the level of thinking $\mathrm{C} 4$ or level of analysis. The percentage is $45 \%$, while others are at levels $\mathrm{C} 3$ and $\mathrm{C} 2$. Level $\mathrm{C} 4$ found in $\mathrm{BC}$ with material related to abstract and physical concepts and biology organ system in humans. However, for levels $\mathrm{C} 2$ and $\mathrm{C} 3$, the cognitive level is applied to content that is often related to the application of healthy lifestyles and prevention of disease.

\section{Assessment of the ability to create concept maps}

Making concept maps in this study has two functions. First, prospective teachers can find out how far important concepts they must teach following $\mathrm{BC}$ demands. That is seen from the limitations that exist on the concept map. Second, prospective science teachers can see the connection between one concept and another so that they can develop systematic teaching material. The data about the ability of pre-service science teacher students in concept mapping can be seen in figure 1 .

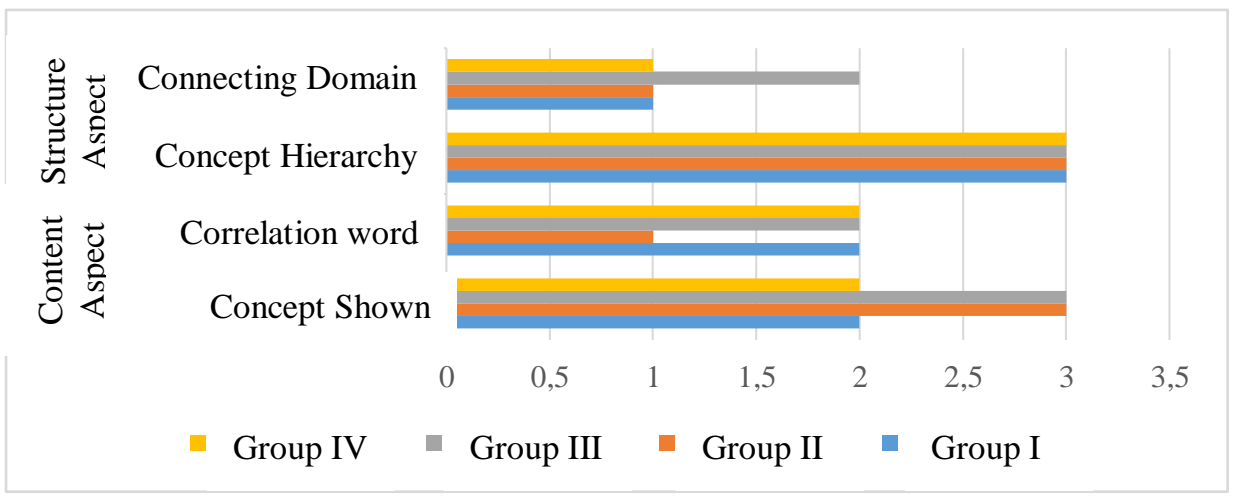

Figure 1. The value of the ability of prospective science teachers in mapping concepts in the 2013 KD Science Curriculum 


\section{Purnomo and Hidayati}

Based on figure 1, all groups showed good skill in compiling a hierarchy of concepts, namely general concepts and specific concepts; indicated by score 3 . For connectivity between one domain and another, it is generally not done - each domain of general concepts networked with particular concepts in the area. In other words, the specific concept of one general concept has not been related to the specific concept of another general concept. For this, only one group showed this connection, but it was not enough so that they got a score of 2 .

In the aspect of content or content, the majority of groups have made concept maps with clear concept hierarchies; the more specific concepts are under a more general concept. This is shown by the number of groups that get the values 2 and 3. For conjunctive substances, the highest value that can be achieved by groups is 2. This means that some propositions for some concepts have not been fully presented.

In conclusion, the concept map made by prospective science teacher students is still at level 1 for structure and level 2 for content (Cañas, Novak, and Reska, 2015). To be more explicit, each concept map that has been made by a group of prospective science teacher students.

Based on the assessment made in the sub-section above, the following is an example of a concept map that has been made by prospective science teacher students. The concept map made consists of concepts of the human digestive system, concept maps of the human reproductive system, concept maps of the soil and fertility, and concept map of the Plant Structure and Technology.

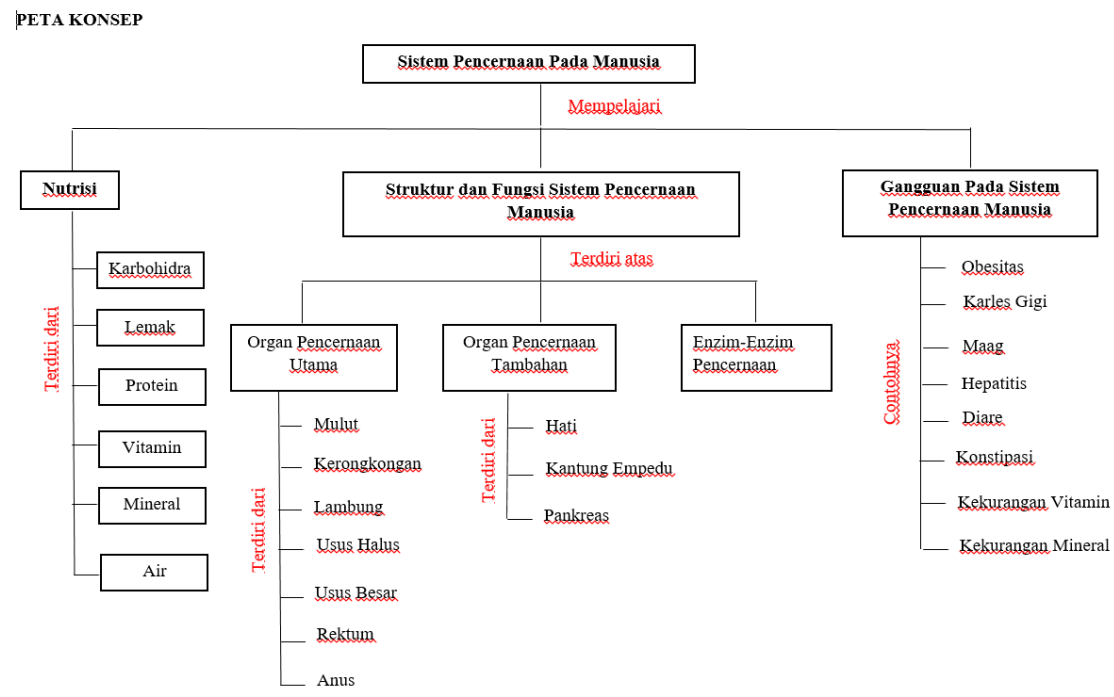

Figure 2. Concept map of the digestive system in humans

The concept map (figure 2) contains sufficient concepts for learning in the material digestive system because a method of systems is described through constituent organs, functions, and disorders that may be experienced by a system. However, the weakness of the concept map above lies in the use of the correlation word. Conjunctions improper, that the word "learn" because these words do not describe how digestive system works, but rather for us to the study of learning. In addition, the concept map above has not connected the domain of one concept to another. There are three main concept domains in the map above, 
namely nutrition, structure and function, and interference. Nutritional areas and functions, for example, can be linked to each other, concerning changes in carbohydrate molecules into glucose by the enzyme ptyalin produced by the glands in the mouth. If concluded, this concept map is at level 1 for structure and level 2 for content adequacy.

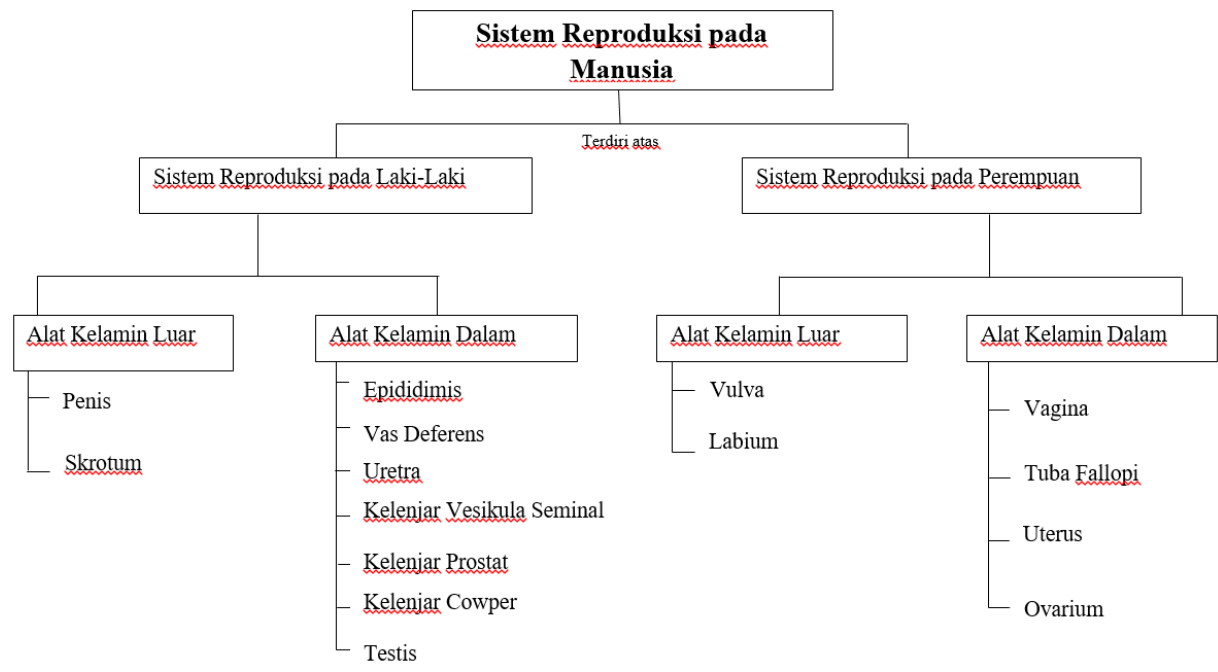

Figure 3. Concept map of the human reproductive system

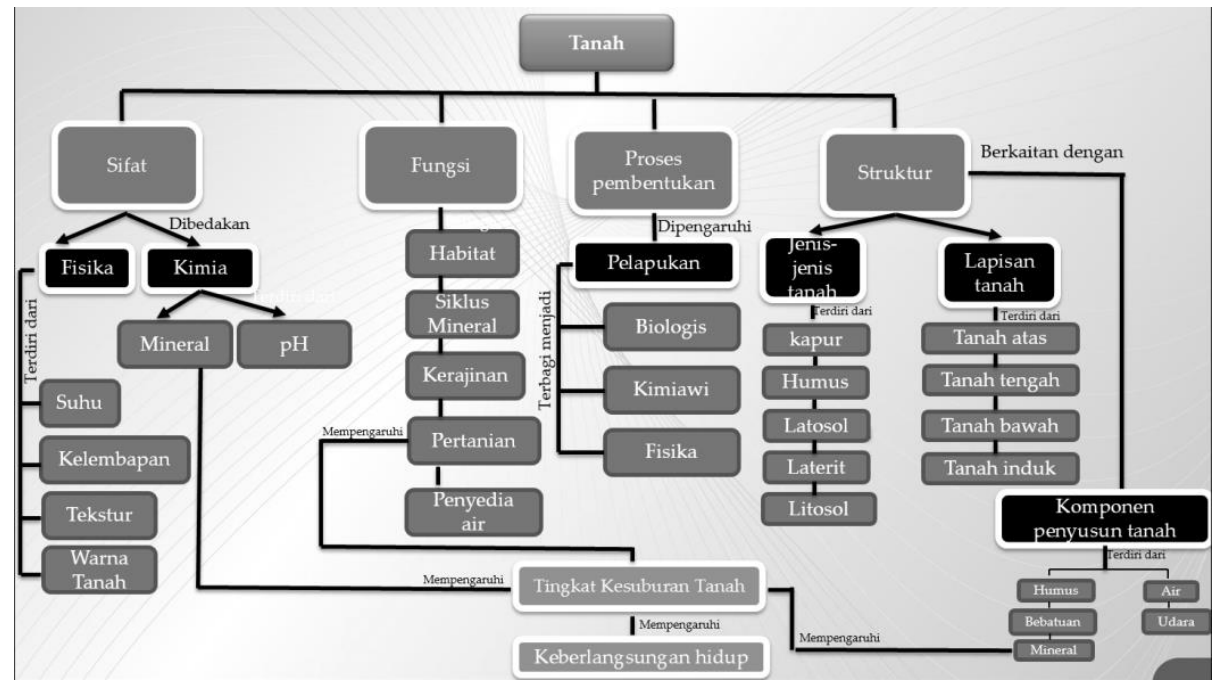

Figure 4. Concepts map of Soil and fertility

Judging from the adequacy of the content, the concept map figure 3 does not present the domain of concepts regarding reproductive system disorders and healthy lifestyles. These domains have the same level as the domain of the concept of the "male reproductive system" and "the female reproductive system." Others, conjunctions for the whole division of concepts are not used so that it makes it difficult to classify concepts. For example, the concept of "external 


\section{Purnomo and Hidayati}

genitals" should have conjunctions "constituent organs." In other words, this concept map, both in structure and content, is at level 1 or is still of low quality.

Unlike the previous two concept maps, the land concept map shows better quality of the structure and content aspects. There are four domains of concepts after the concept of land, namely properties, functions, processes of formation, and structure (figure 4). Each is divided into several specific concepts with explicit conjunctions. The domains of the concept have also been connected, for example, the domain of soil chemistry and the constituent components of the soil. However, domain connectivity can be improved by joining the domain of "soil types" and "nature" of the land. In general, this concept map has level 2 (good) in the area of structure and content.

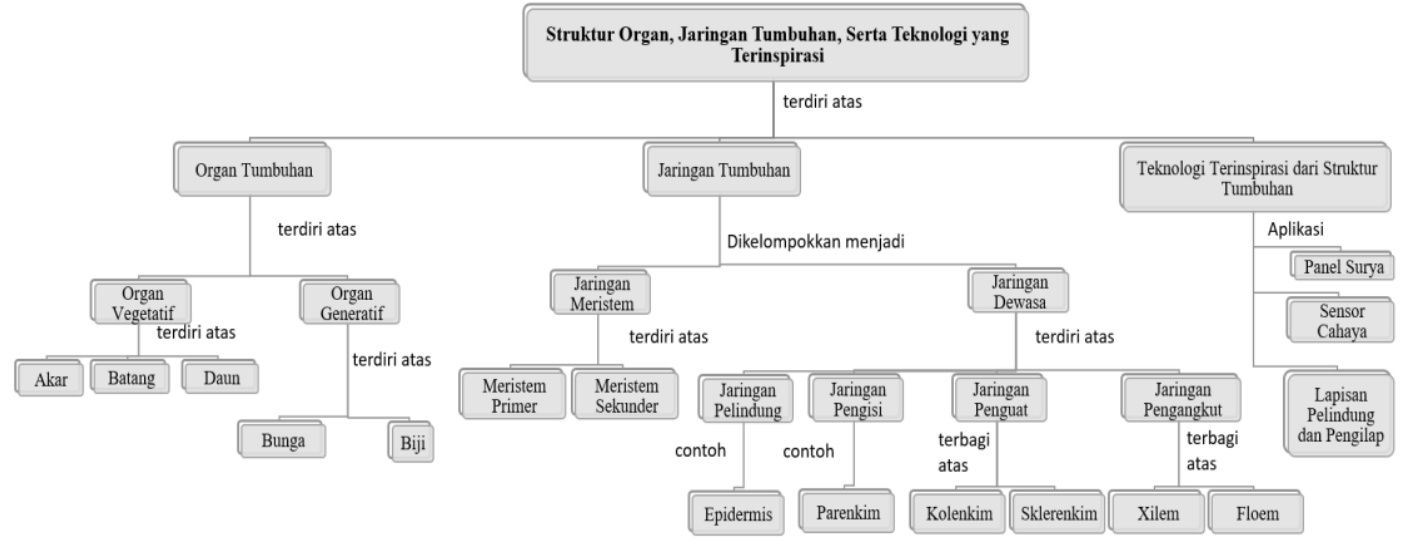

Figure 5. Concepts maps of plant structure and technology

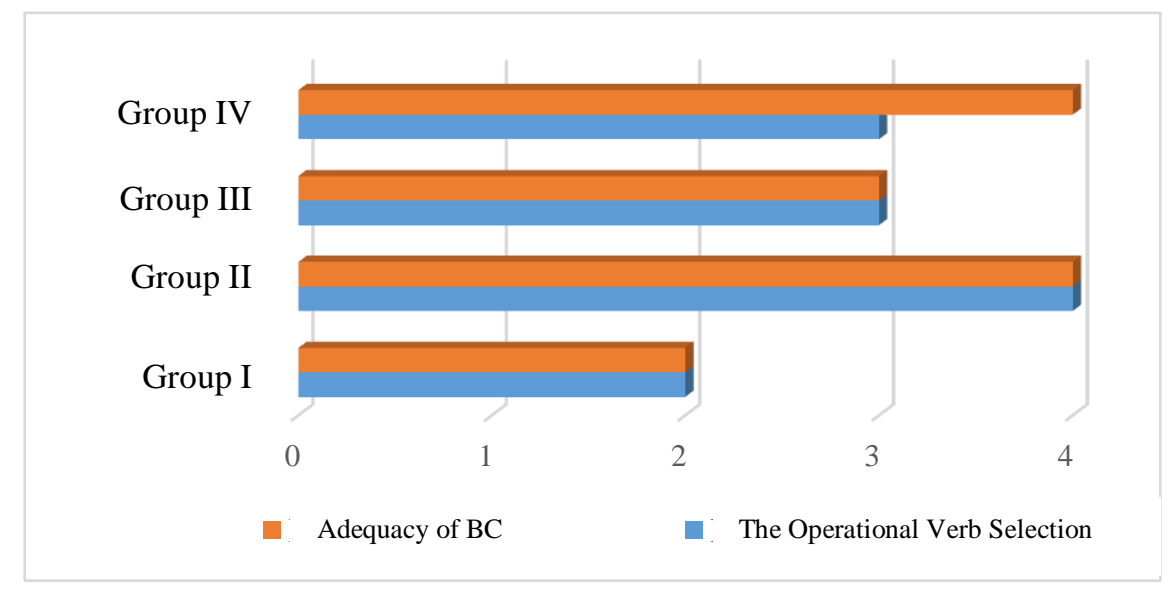

Figure 6. Graph of indicator preparation value 
The Analysis of Pedagogical Content Knowledge

\begin{tabular}{|c|c|}
\hline $\begin{array}{l}\text { 3.5.1. Mengenali berbagai bahan atau zat } \\
\text { makanan. }\end{array}$ & $\begin{array}{l}\text { berhubungan dengan } \\
\text { pencernaan pada manusia }\end{array}$ \\
\hline $\begin{array}{l}\text { 3.5.2. Menjelaskan fungsi dari bahan atau } \\
\text { zat pada makanan. }\end{array}$ & $\begin{array}{l}\text { 3.5.18. Mengenali upaya dalam menjaga } \\
\text { svstem pencernaan pada manusia }\end{array}$ \\
\hline $\begin{array}{l}\text { 3.5.3. Mengidentifikasi bahan makanan dari } \\
\text { produk makanan kaitannya dengan }\end{array}$ & $\begin{array}{l}\text { 3.5.19. Menjelaskan upaya dalam menjaga } \\
\text { system pencernaan pada manusia }\end{array}$ \\
\hline $\begin{array}{l}\text { zat pada makanan. } \\
\text { 3.5.4. Melaksanakan uii bahan makanan }\end{array}$ & berhubungan dengan system \\
\hline $\begin{array}{l}\text { terkait zat (protein, lemak, glukesa) } \\
\text { yang terkandung didalam makanan. }\end{array}$ & $\begin{array}{l}\text { 3.5.18. Mengenali upaya dalam menjaga } \\
\text { system pencernaan pada manusia }\end{array}$ \\
\hline $\begin{array}{l}\text { 3.5.5. Mengenali organ-organ dalam system } \\
\text { pencernaan. }\end{array}$ & $\begin{array}{l}\text { 3.5.19. Menjelaskan upaya dalam menjaga } \\
\text { system pencernaan pada manusia }\end{array}$ \\
\hline $\begin{array}{l}\text { 3.5.6. Menjelaskan fungsi dari organ } \\
\text { pencernaan. }\end{array}$ & \\
\hline $\begin{array}{l}\text { 3.5.7. Menyebutkan bagian dari organ- } \\
\text { organ dalam system pencernaan }\end{array}$ & \\
\hline $\begin{array}{l}\text { 3.5.8. Membedakan organ utama dan organ } \\
\text { tambahan dalam system pencernaan }\end{array}$ & \\
\hline $\begin{array}{l}\text { 3.5.9. Menjelaskan proses pencernaan } \\
\text { secara mekanik }\end{array}$ & \\
\hline $\begin{array}{l}\text { 3.5.10. Menjelaskan proses pencernaan } \\
\text { secara kimiawi }\end{array}$ & \\
\hline $\begin{array}{l}\text { 3.5.11. Membedakan proses pencernaan } \\
\text { makanan secara kimiawi dan } \\
\text { mekanik pada manusia }\end{array}$ & \\
\hline $\begin{array}{l}\text { 3.5.12. Mengenal enzim yang berperan } \\
\text { dalam system pencernaan }\end{array}$ & \\
\hline $\begin{array}{l}\text { 3.5.13. Mengidentifikasi enzim dalam } \\
\text { system pencernaan }\end{array}$ & \\
\hline $\begin{array}{l}\text { 3.5.14. Menyebutkan enzim yang berperan } \\
\text { pada organ disistem pencernaan. }\end{array}$ & \\
\hline $\begin{array}{l}\text { 3.5.15. Menganalisis proses pencernaan pada } \\
\text { manusia beserta senzim yang } \\
\text { berperan didalamnya }\end{array}$ & \\
\hline $\begin{array}{l}\text { 3.5.16. Mengenali berbagai penyakit yang } \\
\text { berhubungan dengan system } \\
\text { pencernaan pada manusia }\end{array}$ & \\
\hline 5.17. Menjelaskan berbaga & \\
\hline
\end{tabular}

Figure 7. Learning indicator errors in digestive system material

Finally, the concept map of plants structure and technology (figure 5) contains the content that is as good as the land concept map. The hierarchical concept has also been compiled, starting from general and specific concepts. However, the concept is not yet connected. The concepts related to protective tissues and fillers can be associated with the composition of plant organs. In addition to connectivity, the main concept of the concept map is not clear because it contains more than one concept. Supposedly, the main concept is plant. For this reason, the concept map based on the content is said to be good, except that the structure needs to be improved again.

\section{The Description of Indicators}

After knowing the mapping of concepts in the scope of the material, prospective science teacher students then develop indicators that illustrate how far the concepts are learned by students later. The indicators made by students include their adequacy at the minimum BC standard. The analysis is not only based on operational verbs in $\mathrm{BC}$ but also its interaction with understanding the material content. The results of the preparation are presented in figure 6 . 


\section{Purnomo and Hidayati}

From picture 6, prospective science teacher students generally have been able to determine the right indicators for science materials according to the demands of the 2013 curriculum. It can be seen that groups 2 to 4 can make indicators with a minimum score of 3 , which means adequacy and cognitive domain of operational verbs, it's good. However, a small number of groups still have confusion in determining the right indicators, such as in group 1 that raises material about the digestive system. When viewed on the indicators made, the error lies in indicator 3.5.4 which is more suitable for core IV competencies (which are related to skills), namely "Carrying out food ingredient tests related to substances (protein, fat, glucose) contained in food." The next mistake is the use of the word "recognize" which is identical to "knowing." This operational verb is difficult to be used as an indicator because the level is not easy to measure.

Referring to the PCK component, through the three elements in figure 7 students can transfer their knowledge plan to learn (pedagogical aspects). The translation of $\mathrm{BC}$ into indicators requires the ability to analyze and compile learning indicators systematically. This arrangement will later determine the material organization and mind mapping to comprehend essential material as a whole. The concept map here serves to facilitate a broad picture of essential material that will be taught by prospective science teacher students in teaching programs.

\section{Conclusion}

The skill of analyzing essential science materials for prospective science teacher students shows a fairly good understanding, regarding aspects of PCK.
Little deficiencies occur in aspects of making indicators and concept maps. This is sufficiently supported by the learning used, discussion-presentation methods, and courses programmed by students, School Science Analysis.

\section{References}

Cañas, A. J., Novak, J. D., dan Reska, P. (2015). How Good is My Concept Map? Am I Good Cmapper? Knowledge Management \& ELearning. Vol. 7, no. 7, hal. 6-19.

Cheng, J.H., Jang, S. J., dan Chen, P. J. (2014). Using Wikis and Collaborative Learning for Science Teachers' Professional Development. Journal of Computer Assisted Learning. Vol. 31, no. 4, hal. 330-344 Doi: $10.1111 /$ jcal.12095

Fauziah, Y. N. (2011). Analisis Kemampuan Guru dalam Mengembangakan Keterampilan Berpikir Kreatif Siswa Sekolah Dasar Kelas V pada Pembelajaran Ilmu Pengetahuan Alam. Jurnal ISSN 1412-565X, Edisi Khusus No, 2, 98-106.

Jüttner, Boone, W. Park, S. \& Neuhaus, B. J. (2013). Development and Use of a Test Instrument to Measure Biology Teachers' Content Knowledge (CK) and Pedagogical Content Knowledge (PCK). Educational Assessment, Evaluation and Accountability. Vol. 25, Hal. 45-67. Doi: 10.1007/s11092-013-9157-y

Kartal, T., Ozturk, N., dan Ekici, G. (2012). Developing Pedagogical Content Knowledge in Preservice Science Teachers Through Microteaching Lesson Study. 
Procedia: Social and Behavioral Sciences. Vol. 46, Hal. 27532758.

Lazarowitz, R., Lazarowitz, R-H., dan Baird, H. J. (1994). Learning Science in a Cooperative Setting: Academic Achievement and Affective Outcomes. Journal of Research in Science Teaching. Vol. 31, No. 10, Hal. 1121-1131.

Mondejar, Loida $\mathrm{M}^{\mathrm{a}}$ López dan Pastor, Lina $\quad M^{\mathrm{a}}$ Tomás. (2017). Development of Socio-emotional Skills through Cooperative Learning in a University Environment. Procedia: Social and Behavioral Sciences. Vol. 237, Hal. 432-437.

Nancy Lee Ming See. (2014). Mentoring and Developing Pedagogical Content Knowledge in Beginning Teachers. Procedia: Behavioral and Social Sciences. Vol. 123, hal. $53-62$.

Pudjiastuti, E., T. J. Raharjo, dan A. T. Widodo. (2012). Kompetensi Profesional, Pedagogik Guru Ipa, Persepsi Siswa Tentang Proses Pembelajaran, Dan Kontribusinya Terhadap Hasil Belajar Ipa Di Smp/Mts Kota Banjarbaru. Innovative Journal of Curriculum and Educational Technology. Vol. 1, No. 1, hal. 22-29. Diakses melalui

http://journal.unnes.ac.id/sju/inde x.php/ujet

Purwana, U. (2010). Profil kompetensi pedagogik guru IPA-fisika SMP dan MTs di wilayah Paseh Kabupaten Sumedang melalui kegiatan lesson study berbasis MGMP. Bandung: FPMIPA UPI.
Yohafrinal, Damris, dan Risnita. (2015). Analisis Pedagogical Content Knowledge (PCK) Guru MIPA di SMA Negeri 11 Kota Jambi. Edu Sains. Vol. 4, No. 2, Hal. 15-24. 